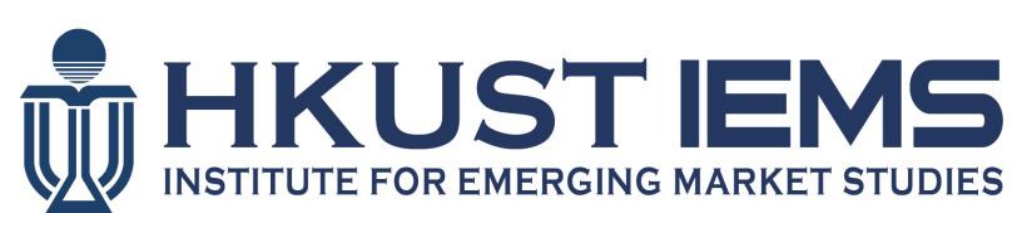

\title{
Processing Trade, Productivity and Prices: Evidence from a Chinese Production Survey
}

\author{
Yao Amber LI, Valérie SMEETS, \\ Frédéric WARZYNSKI
}

HKUST IEMS Working Paper No. 2018-58

November 2018

\footnotetext{
HKUST IEMS working papers are distributed for discussion and comment purposes. The views expressed in these papers are those of the authors and do not necessarily represent the views of HKUST IEMS.

More HKUST IEMS working papers are available at: http://iems.ust.hk/WP
} 


\title{
Processing Trade, Productivity and Prices: Evidence from a Chinese Production Survey
}

\author{
Yao Amber LI, Valérie SMEETS, Frédéric WARZYNSKI \\ HKUST IEMS Working Paper No. 2018-58 \\ November 2018
}

\begin{abstract}
In this paper, we use a detailed production survey in the Chinese manufacturing industry to estimate both revenue and physical productivity and relate our measurements to firms' trade activity. We find that Chinese exporters for largely export oriented products like leather shoes or shirts appear to be less efficient than firms only involved on the domestic market based on the standard revenue productivity measure. However, we show strong positive export premium when we instead consider physical productivity. The simple and intuitive explanation of our results is that exporters charge on average lower prices. We focus more particularly on the role of processing trade and find that price differences are especially large for firms involved in this type of contractual arrangements. We suggest three reasons to explain this result. First, lower prices may simply be due to a mechanical effect as processing trade products are not subject to tariffs nor have to pay VAT. Second, some types of processing trade activities entail that the processing trade firm receives the inputs for free from the contracting firm, therefore artificially depressing the values of inputs or materials used for the firm's production. Third, lower prices may also be a consequence of transfer pricing, as multinationals involved in FDI in China may alter the price charged for inter-company transactions to shift funds within the organization.
\end{abstract}

Keywords: $\quad$ trade activity, revenue, productivity, export

\section{Author's contact information}

\author{
Yao Amber Li \\ Institute of Emerging Market Studies \\ Hong Kong University of Science and Technology \\ E:yaoli@ust.hk
}

Valérie Smeets

Aarhus University

E:vas@asb.dk

Frédéric Warzynski

Aarhus University

D: fwa@asb.dk 


\title{
Processing Trade, Productivity and Prices: Evidence from a Chinese Production Survey*
}

\author{
Yao Amber $\mathrm{Li}^{\dagger} \quad$ Valérie Smeets ${ }^{\ddagger} \quad$ Frédéric Warzynski ${ }^{\S}$
}

November 7, 2018

\begin{abstract}
In this paper, we use a detailed production survey in the Chinese manufacturing industry to estimate both revenue and physical productivity and relate our measurements to firms' trade activity. We find that Chinese exporters for largely export oriented products like leather shoes or shirts appear to be less efficient than firms only involved on the domestic market based on the standard revenue productivity measure. However, we show strong positive export premium when we instead consider physical productivity. The simple and intuitive explanation of our results is that exporters charge on average lower prices. We focus more particularly on the role of processing trade and find that price differences are especially large for firms involved in this type of contractual arrangements. We suggest three reasons to explain this result. First, lower prices may simply be due to a mechanical effect as processing trade products are not subject to tariffs nor have to pay VAT. Second, some types of processing trade activities entail that the processing trade firm receives the inputs for free from the contracting firm, therefore artificially depressing the values of inputs or materials used for the firm's production. Third, lower prices may also be a consequence of transfer pricing, as multinationals involved in FDI in China may alter the price charged for inter-company transactions to shift funds within the organization.
\end{abstract}

\section{Introduction}

Major improvements in information and communication technologies, falling trade costs and the gradual openness of former socialist countries have led to dramatic changes in the way firms organize their production. Many companies in the Western world have

*We thank Andrew Bernard, Simeon Djankov, Edwin Lai, Sandra Poncet, Chad Syverson, Yuan Zi and seminar participants at Aarhus, NOITS2016, ADI2016, Beijing Forum 2016, EITI 2017 and CAED 2017 for useful comments and discussions. All errors are ours.

$\dagger$ Hong Kong University of Science and Technology, email: yaoli@ust.hk

‡Aarhus University, email: vas@asb.dk

$\S$ Aarhus University, email: fwa@asb.dk 
offshored part of their production process to developing countries, taking advantage of lower labor costs. This has led to a fragmentation of the supply chain and the emergence of global value chains (see e.g. Antràs, 2016). A particular form of fragmented production is processing trade. Under this regime, firms ship materials, parts and components to an offshore location where they are further processed and assembled before being re-exported as final goods. Imports and exports under processing trade are typically shielded from tariffs and involve other fiscal advantages, making it particularly attractive. Processing trade represents a large share of total exports for developing countries. Between 2000 and 2008, nearly a fifth of exports from developing countries (half for China) came from processing trade (WTO, 2010). By 2006, 130 countries had established 3500 export processing zones.

While this topic has attracted significant attention both from policy makers and academic researchers, little is known about the link between firms' performance and the fragmentation of production. The difficulty to answer that question arises from the various measurement problems introduced by this way of organizing production. In this paper, we investigate the role of processing trade and its pricing implications on firm-level productivity using a unique combination of datasets from China. We provide evidence of a large bias toward firms engaged in processing trade that is mostly explained by price differences between firms involved in processing trade and firms involved in regular trade.

To allow for pricing heterogeneity in our framework, we follow Foster, Haltiwanger and Syverson (2008) and estimate production functions using both deflated revenue and physical quantity as a measure of output. This gives us two measures of total factor productivity: the standard revenue based productivity (TFPR) and the physical productivity (TFPQ). The former measure of productivity bundles prices and technical efficiency difference together, while the second measure of productivity allows us to separate pricing heterogeneity from technical efficiency. We find that the productivity premium of Chinese exporters is seriously affected by prices differences among exporters and non exporters. Not controlling for prices differences leads to an negative bias on the estimation of the productivity premium for Chinese exporters. Chinese exporters do not appear to be more productive than firms dedicated solely to the domestic market when we use the standard measure of productivity, and in fact they appear less productive. The result reverses and Chinese exporters enjoy a large productivity premium when we use the physical measure productivity. We show that exporters have lower prices than non exporters and that those effects are mostly driven by processing trade.

The datasets we use in this paper are a combination of accounting data, customs data and production survey data for China. Our sample period is from 2000 to 2006. 
Accounting data are used to retrieve usual balanced sheet information about Chinese firms' inputs use and revenues. The production survey reports detailed information about the physical quantities of the goods produced by Chinese firms. The customs data allows us to identify which firms are involved in exporting and in processing trade. We focus our analysis on a subset of products in which Chinese firms have become a dominant force, to a large extent thanks to the existence of this institutional feature of processing trade. Most of our analysis is about the footwear industry, a very good candidate for our empirical strategy, especially leather shoes, although we experiment with a few other products to assess the validity of our results.

Price differences between firms involved in processing trade relative to firms doing regular trade can come from various channels. First, inputs and outputs of processing trade firms are exempted from tariffs, giving them a cost advantage. There are also additional fiscal benefits such as VAT exemption. Second, a special type of processing trade involves the free provision of inputs to the assembly firm. This mechanically reduces the material costs and can affect the price charged for the final good. Third, foreign firms involved in FDI might use transfer pricing and strategically charge lower prices to shift profit between locations.

Aside from shedding light on the implications of processing trade for productivity measurement and pricing, we contribute to the debate about the surprising fact found in previous papers that exporters are less productive than domestic firms, especially in labor intensive industries (see Lu, 2010 for early evidence). While several explanations have been provided for this result, varying from the presence of export subsidies or easy access to financing; or the fact that many Chinese manufacturers engage in processing trade (e.g. Dai, Maitra and Yu, 2016), none have stressed the implications for productivity measurement of pricing differences between regimes of trade.

We also contribute to a growing literature investigating the role of output pricing heterogeneity bias on the measurement of productivity (e.g. Klette and Griliches, 1996; Levinsohn and Melitz, 2001; Kugler et al., 2004; Foster Haltiwanger and Syverson, 2008; De Loecker, 2011). Our results are closely related to recent papers that show that export premium and learning by exporting are estimated with a different magnitude when looking at physical rather than revenue productivity (Smeets and Warzynski, 2013; Garcia-Marin and Voigtlander, 2013).

Our paper is also related to a more recent body of research investigating the implications of input price heterogeneity bias. When firms produce goods of different level of quality within the same product market, they are likely to use inputs of different level of quality as well. This might bias our productivity estimates if we use a common deflator 
for materials. To deal with this issue, we follow De Loecker et al. (2016) who provide a simple and elegant framework to control for input price heterogeneity. We apply their algorithm to our sample of Chinese firms and show that taking into account input price differences significantly affects the coefficients of our production function.

The rest of the paper is organized as follows. Section 2 describes the datasets that we use with a special emphasis on the production survey which is relatively unknown. Section 3 presents our simple empirical methodology based on Foster, Haltiwanger and Syverson (2008). In section 4, we discuss our results. We first comment on the estimation of the production function using physical quantity as measure of output and how the resulting physical productivity estimates differ from standard revenue based measures. We then relate our productivity measures to export and price behavior, as well as we test the robustness of our findings. Section 5 concludes.

\section{Data}

We use three data sources to conduct our study: (i) the National Bureau of Statistics of China firm-level accounting data that reports revenue-based information on inputs and outputs of production, (ii) the National Bureau of Statistics of China firm-product level production survey that contains physical output quantity information, and (iii) the Chinese Customs data. The first two databases use the same firm identity code while the last one adopts a different firm ID system. We managed to merge these two sets of firm identification codes based on the contact information of manufacturing firms, as no consistent coding system of firm identity is available for these two databases. Our matching procedure is carried out in three steps: (1) by company name, (2) by telephone number and zip code, and (3) by telephone number and contact person name (see a detailed description of the matching process in Fan, Li, and Yeaple, 2015). Now we discuss each of the three databases in turn.

\subsection{Accounting data}

This now standard dataset has been used in many papers about firm productivity in China. The National Bureau of Statistics of China firm-level accounting data are drawn from Annual Surveys of Industrial Firms (ASI) for all state-owned enterprises (SOEs) and non-state-owned enterprises with annual sales of at least five million RMB. The NBSC accounting database contains detailed firm-level accounting information on Chinese manufacturing enterprises, including employment, capital stock, gross output, value added, and firm identification information (e.g., company name, telephone number, zip code, 
contact person, etc.). ${ }^{1}$ With regard to misreporting cases, we use the following protocols to remove unsatisfactory observations in accordance with the previous literature and General Accepted Accounting Principles: (i) total assets must be higher than liquid assets; (ii) total assets must be higher than total fixed assets; (iii) total assets must be higher than the net value of fixed assets; (iv) a firm's identification number cannot be missing and must be unique; and (v) the established time must be valid.

\subsection{Production Survey}

This quantity production survey dataset is collected and maintained by the National Bureau of Statistics of China, for the purpose of monitoring the production of major industrial products by all state-owned enterprises (SOEs) and above-scale non-state-owned manufacturing firms in China. ${ }^{2}$ Our sample contains more than 800 5-digit product codes that are listed as main industrial product and approximately 186,000 manufacturing firms.

The survey covers roughly the same firms in manufacturing than in the accounting dataset. Firms are asked to name the products that they make and the physical quantity produced. The survey is monthly (except in January) but firms are also asked about their cumulative production over the year. Given that our accounting dataset provides yearly information about nominal sales and input use, we only consider the cumulative quantity produced provided at the end of December of each year.

A product is defined at a slightly more aggregated level than what is done in the US or in Europe. We consider more specifically a series of products that can be matched relatively easily within HS2 categories. We use leather shoes as our key product (product code 5901), although we will also experiment with various alternative products. Leather shoes span over several HS4 categories: 6401 to 6405.

\subsection{Customs data}

To identify firms involved in processing or ordinary trade, we use the commonly used Chinese customs data (see e.g. Manova and Zhang, 2012). The Chinese Customs Database covers the universe of all Chinese trade transactions for the years 2000-2006, including import and export values, quantities, product classifications, source and destination countries, custom's regime (e.g. "Processing and Assembling" and "Processing with Imported Materials"), type of enterprise (e.g. state owned, domestic private firms, foreign invested, and joint ventures), and contact information for the firm (e.g., company name, telephone,

\footnotetext{
${ }^{1}$ This firm identification information is used to match the NBSC database with the customs database.

${ }^{2}$ During the sample period 2000-2006, the above-scale manufacturing firms refer to those with annual sales of at least 5 million RMB (Chinese currency).
} 
zip code, contact person). ${ }^{3}$

The initial customs data at the HS 8-digit product level are aggregated to the HS 6-digit level so as to be able to concord it consistently over time because the concordance for HS 8-digit codes in China is not available to us. To ensure the consistency of the product categorization over time, we adopt HS 6-digit codes maintained by the World Customs Organization (WCO) and use the conversion table from the UN Comtrade to convert the HS 2002 codes into the HS 1996 codes.

We aggregate exports (and imports) at the firm-HS6-year level and by type of transaction (processing, ordinary or hybrid trade). We then categorize firms according to two dimensions: 1) whether the firm is involved only in processing trade, ordinary trade or a mix of the two (hybrid); 2) whether the firm is only exporting products that it declares to be producing or not. Through the first dimension, we want to deal with how firms involved in processing trade might have different production functions but also different prices. Through the second dimension, we want to address the issue of carry along trade (CAT) and its implications for our measurement.

\subsection{Processing, ordinary and hybrid trade}

Table 1 provides summary statistics about the export behavior of firms in our sample and the mode of export. We observe that a large proportion of firms in the leather shoes industry export at the beginning of the period, but the share of exporters is declining over the years, possibly as the domestic market becomes more important.

Regarding the mode of export, we see that the share of processing trade remains relatively constant (declining slightly from $26 \%$ to $22 \%$ ), while the share of hybrid trade goes down dramatically from $59 \%$ to $35 \%$, implying a large increase in the relative share of ordinary trade.

In value, the share of export transactions under the mode of processing trade has declined in value from $92 \%$ in 2000 to around $73 \%$ in 2006. The share of import transactions under the regime of processing trade is stable and around $95 \%$.

\subsection{Carry along trade}

In our analysis, we focus on single product firms, i.e. those firms that report producing only one product. When comparing the information from the production survey and the customs dataset, we realized that firms sometimes export products that they do not

\footnotetext{
${ }^{3}$ Note that the Chinese Customs data we use in this paper contain only realized transactions rather than the "reported" transactions from invoice records. Thus, we are not concerned about the possibility of fake invoicing.
} 
necessarily (report they) produce. This has been labeled in the literature as carry along trade (Bernard et al., 2012). This might be problematic if firms employ part of their inputs for exporting goods they do not produce, as we would wrongly allocate these inputs to production. ${ }^{4}$ In our sample, more than $75 \%$ of firms only export shoes and $95 \%$ of firms only export shoes and part of shoes.

\section{Methodology}

Our aim is to show that the productivity measure commonly used in the literature suffers from a measurement bias referred to as pricing heterogeneity bias. Once we are able to define a measure that corrects for this bias, we obtain a very different message about the link between productivity and exporting.

To illustrate the problem, consider a production function:

$$
Q_{i t}=\Theta_{i t} f\left(X_{i t}\right)
$$

where $Q$ is a measure of output, $X$ is a vector of inputs, $\Theta$ is an index of technical progress, $i$ is a firm index and $t$ a time index.

Assuming a Cobb-Douglas function and taking logs:

$$
q_{i t}=\alpha x_{i t}+\vartheta_{i t}
$$

where lower cases denote logs, $\alpha$ is a vector of parameters to be estimated, $\vartheta_{i t}=\omega_{i t}+$ $\epsilon_{i t}, \omega$ is a measure of "true" (observed by the manager but not by the econometrician) productivity and $\epsilon$ is a true noise (unexpected shock to productivity).

Most researchers use deflated revenue as a proxy for $Q\left(\widetilde{R}_{i t}=R_{i t} / P_{j t}\right.$ where $R_{i t}=$ $P_{i t} Q_{i t}$ is firm revenue, $P_{i t}$ is the price set by the firm, or a firm-specific price index; and $P_{j t}$ is an industry-level deflator, i.e. a price index in industry $j$ at time $t$, typically provided by the statistical office based on micro-surveys such as the one we use in this study) so that our typical regression will be:

$$
\widetilde{r}_{i t}=\alpha x_{i t}+\left(p_{i t}-p_{j t}\right)+\omega_{i t}+\epsilon_{i t}
$$

where $\left(p_{i t}-p_{j t}\right)$ measures the difference between the log of the firm-level price index and the industry level price index. We refer to this difference as the price bias. Its presence implies that productivity will be badly measured as the price bias will be part of the error term and will include a (possibly firm-specific) demand shock. This bias is stronger the more there is pricing heterogeneity in the market. In addition, if pricing

\footnotetext{
${ }^{4}$ See Smeets and Warzynski (2014) for similar discussion about subcontracting and offshoring.
} 
varies systematically depending on firm characteristics such as exporting status or the type of export (processing vs ordinary), not accounting for it would lead to the wrong conclusions.

We refer to the previous measure as revenue productivity $(T F P R)$. Following Foster, Haltiwanger and Syverson (2008), we use our production survey to compute a measure of physical productivity $(T F P Q)$ that results from the estimation of the alternative regression:

$$
q_{i t}=\alpha x_{i t}+\omega_{i t}+\epsilon_{i t}
$$

where $q_{i t}$ is the physical quantity reported by the firm in the survey. It is obvious that, in this case, the measure does not suffer from the pricing heterogeneity bias.

As discussed in De Loecker et al. (2016), a similar concern affects our input variables, in particular materials. We follow their suggestion and add price and market share in our control function when estimating the production function. To address the well known endogeneity concern, we follow their modified version of Wooldridge (2009). (See online appendix for more details.) The technique is applied using both deflated revenue and physical quantity as left hand side variable.

In the rest of our analysis, we look at how our two measures of productivity relate to exporting behavior and try to explain why we observe dramatic differences.

\section{Results}

\subsection{Production function estimation}

Table 2 shows the OLS coefficients and the median output elasticities from the translog analysis using DLGKP algorithm for all single product firms producing leather shoes. The left side of panel A shows the results of the estimation using deflated turnover from the accounting dataset, while the right side physical quantity from the production survey as a measure of output. Following the suggestion of DLGKP, we add a proxy for output price in our polynomial to control for input price heterogeneity bias. ${ }^{5}$ While the value of production is not available in the production survey, we observe sales from the accounting data. Our price proxy is simply sales divided by physical quantity. Since we only consider single product firms in our analysis, we make the explicit assumption that firms report their product portfolio accurately and also that most of the firm revenue comes from product sales (probably not a bad assumption for the subset of firms that we consider).

\footnotetext{
${ }^{5}$ The measurement of material costs has been shown to be especially problematic with Chinese data see Feenstra, Li and Yu (2014); on the importance of input price bias, see also Grieco et al. (2016) and Attalay (2014).
} 
We will provide several tests for this assumption using the customs data to double check the validity of our proxy.

Looking at the OLS coefficients, we observe that the coefficient of material is higher with deflated revenue than with physical quantity. The coefficient of capital is low in both cases but significant with deflated revenue. Moving to the DLGKP results, the coefficients become more similar between the

\subsection{Export Premium}

The bottom part of both panels in table 2 shows the export premium under all the various specifications chosen. We find robust positive exporter premium when we consider physical productivity but negative ones when we use revenue TFP. Looking at TFPQ, it looks like the size of the premium is larger when using more sophisticated methods dealing with endogeneity. The method does not appear to matter for revenue TFP. The negative coefficient is small and around $2 \%-4 \%$.

This result can be explained by looking at pricing behavior by export status. Exporters on average charge prices $20 \%$ lower than non exporters.

\subsection{Processing and Regular Trade}

We then match our production and accounting data with the customs data information in order to assess whether productivity is related to exporting depending on the mode of exports, as has been suggested by Dai, Maitra and Yu (2015). Table 3 shows the relationship between our various measures of TFP and the mode of export. Looking at TFPR fist, it looks like firms involved in ordinary trade are less productive, followed by firms only doing processing trade. Both types have lower revenue productivity than non exporters. Firms involved in hybrid have a slightly higher TFPR than domestic firms. Turning to TFPQ, the reverse is true. Firms involved in regular trade and only processing trade outperform non exporters and firms doing hybrid trade. Again, these results can be explained by how these different modes of transaction are related to firms' price. Firms involved in processing trade have prices that are $42 \%$ lower than domestic firms. For firms doing ordinary trade, prices are $32 \%$ lower, while firms doing hybrid trade do not differ from domestic firms in terms of pricing. 


\subsection{Additional findings and robustness}

\subsubsection{Export and domestic prices}

Customs data also provide value and quantity at the HS6 level, so we can compute a proxy for export price. We use this proxy to understand the role of processing trade and to look at the relationship between export price and production price. This is a way to validate our production price proxy. Table 4 shows the results. In line with our previous findings, export prices under the processing trade regime are around $9.4 \%$ lower than under other transaction modes. We also observe that our two price proxies correlate well.

\subsubsection{Controlling for ownership and location}

The decision to engage in processing is intrinsically related to both the location decision and the ownership type (nationality of the owner). Many foreign firms were attracted in export processing zones through its direct fiscal (and other) advantages that it conveyed, in addition to low Chinese labor cost.

Location is provided though a 6 -digit district code. Ownership is divided into several categories: state owned enterprise (SOE), domestic private, joint venture, multinational enterprise (MNE) and other. The Chinese data also makes a distinction between MNE's from Hong Kong, Macau and Taiwan on the one hand, and from OECD countries on the other. Since there are only a few SOE's involved in the leather shoes market, we omit them from our analysis.

Table 5 shows the distribution of the various ownership types for our sample of matched exporters. It clearly shows that MNE's are more likely to be using processing trade than domestic firms.

We next replicate our results from tables 2 and 3 with these additional variables as control. Controlling for location captures several other aspects such as the benefits to be located in clusters or the effect of local competition.

Results are shown in tables 6 and 7 . The main results remain relatively robust to the introduction of these additional variables. Exporters have higher physical productivity but lower prices, and this is especially true for firms doing processing trade. We also provide additional findings about the link between productivity and ownership. In particular, MME's from Hong Kong, Macau and Taiwan have higher TFPQ but much lower prices.

As noted in previous research (e.g. Dai et al., 2016), processing trade can itself be divided in two separate modes: firms receiving inputs for free (pure assembly firms) and firms involved in processing trade but acquiring inputs themselves on the market. Our hypothesis is that the latter group of firms will experience a stronger distortion in the price they charge than the former. We test it in table 8 . Indeed, we observe that pure 
assemblers have much higher physical productivity than non exporters and firms involved in other types of trade modes, but this is entirely explained by the fact that they charge lower prices in the same proportion (around 60\%).

\subsubsection{Subsidies}

Another reason why firms might have lower prices is because they receive subsidies from the state, especially in relationship with export share requirement. These types of subsidies have often been claimed in the literature but are typically hard to observe in accounting data (see the discussion in Defever and Riaño, 2017).

Our accounting data actually contains some information about subsidies, although it does not distinguish between types of subsidies. Not surprisingly, most firms report no subsidies at all. However, some do, even though the amount reported is very tiny in most cases. Based on this information, we compute two dummy variables: one equal to 1 if the firm received a subsidy (and 0 otherwise); and another one equal to 1 if the firm receives a subsidy at least equivalent to $1 \%$ of its turnover (and 0 otherwise). For around $11 \%$ of our observations, firms report having received a subsidy, but this rate is much higher for exporters $(14.1 \%)$ than for non exporters $(4.17 \%)$. The number is much lower if we use the more constraining definition (around 1.4\%) and does not vary as much by exporting status. Perhaps more surprisingly, among exporters, firms doing ordinary trade and hybrid firms are more likely to be recipient of these subsidies. This might suggest that direct export subsidies are not included in the subsidy variable and our variable measures other types of subsidies.

When we include subsidies in our estimation, all our results remain robust. Subsidies do not appear to be strongly related to productivity or prices once we control for mode of transaction.

\section{Conclusion}

Using a rich data about physical production of Chinese firms, we estimate revenue and physical productivity for firms engaging in the production of export oriented goods, with a particular focus on leather shoes producers. We find that exporters appear less efficient when looking at revenue productivity, but are actually much more efficient when we consider physical productivity. This difference is explained by pricing differences between firms: exporters charge on average lower prices by a margin of around $20 \%$.

We relate our findings to an important institutional feature of Chinese manufacturing that has facilitated the development of exporting capabilities over the last twenty years: 
processing trade. In this type of contractual agreements, Chinese firms compete in price to assemble final goods for their clients and use their competitive advantage coming from lower labor costs, or also lower input costs, especially in the case of pure assemblers.

While our work unveils interesting stylized facts, we want to expand our analysis to better understand the origin of pricing heterogeneity. We want to separate the various explanations as of why the prices charged by processing trade firms are lower. There are least three reasons we believe may drive large prices differences among Chinese exporters, especially for firms involved in processing trade. First, lower prices may simply be due to a mechanical effect as processing trade products are not subject to tariffs nor have to pay VAT. Second, some types of processing trade activities entail that the processing trade firm receives the inputs for free from the contracting firm. This will artificially depress the values of inputs or materials used for the firm's production. Third, lower prices may also reflect transfer pricing. If a firm's entities are subject to different tax regimes, the multinational may alter the price charged for inter-company transactions to shift funds within the organization. We leave this analysis for future research.

\section{References}

[1] Antràs, P., 2016. Global Production: Firms, Contracts, and Trade Structure. Princeton University Press.

[2] Bernard, A., E. Blanchard, I. Van Beveren and H. Vandenbussche, 2012. MultiProduct Exporters, Carry-Along Trade and the Margins of Trade. NBER Working Paper \#18246.

[3] Bernard, A. B. and Jensen, J. B., 1995. Exporters, Jobs, and Wages in US Manufacturing. Brookings Papers on Economic Activity: Microeconomics, 67-112.

[4] Bernard, A. B. and Jensen, J. B., 1999. Exceptional Exporter Performance: Cause, Effect, or Both? Journal of International Economics 47, 1-25.

[5] Bernard, A. B., Jensen, J. B., Redding, S. and Schott, P., 2015. Global Firms. Working Paper.

[6] Brandt, L. and Morrow, P., 2016. Tariffs and the organization of trade in China. Journal of International Economics 104, 85-103.

[7] Dai, M., Maitra, M. and Yu, M., 2016. Unexceptional Exporter Performance in China? The Role of Processing Trade. Journal of Development Economics 121, 177 189. 
[8] Defever, F. and Riaño, A., 2017. Subsidies with export share requirements. Journal of Development Economics 126, 33-51.

[9] De Loecker, J., 2011. Product Differentiation, Multi-Product Firms and Estimating the Impact of Trade Liberalization on Productivity. Econometrica 79, 1407-1451.

[10] De Loecker, J., Goldberg, P., Khandelwal, A. and Pavcnik, N., 2016. Prices, markups and Trade Reform. Econometrica 84, 445-510.

[11] Dhyne, E., Petrin, A., Smeets, V. and Warzynski, F., 2017. Import Competition, Productivity and Multi-Product Firms. Work in progress.

[12] Fan, H., Li, Y. A., and Yeaple, S. R., 2015. Trade Liberalization, Quality, and Export Prices. Review of Economics and Statistics 97, 1033-1051.

[13] Feenstra, R.C., Li, Z. and Yu, M., 2014. Exports and Credit Constraints under Incomplete Information: Theory and Evidence from China. Review of Economics and Statistics 96, 729-744.

[14] Foster, L., Haltiwanger, J. and Syverson, C., 2008. Reallocation, Firm Turnover, and Efficiency: Selection on Productivity or Profitability? American Economic Review 98, 394-425.

[15] Garcia-Marin, A. and Voigtländer, N., 2013. Exporting and plant-level efficiency gains: It's in the measure. NBER Working Papers \#19033.

[16] Klette, T. J. and Griliches, Z., 1996. The Inconsistency of Common Scale Estimators When Output Prices Are Unobserved and Endogenous. Journal of Applied Econometrics 11, 343-361.

[17] Levinsohn, J. and Melitz, M., 2001. Productivity in a Differentiated Products Market Equilibrium. Mimeo.

[18] Lu, D., 2010. Exceptional Exporter Performance? Evidence from Chinese Manufacturing Firms. Mimeo, University of Chicago.

[19] Manova, K. and Zhang, Z., 2012. Quality Heterogeneity across Firms and Export Destinations. Quarterly Journal of Economics 127, 379-436.

[20] Roberts, M. and Supina, D., 2000. Output price and markup dispersion in micro data: the roles of producer heterogeneity and noise. Industrial Organization 9, 1-36. 
[21] Roberts, M., Xu, D., Fan, X. and Zhang, S. (2016), A Structural Model of Demand, Cost, and Export Market Selection for Chinese Footwear Producers, working paper, Penn State.

[22] Smeets, V. and Warzynski, F., 2013. Estimating productivity with multi-product firms, pricing heterogeneity and the role of international trade. Journal of International Economics 90, 237-244.

[23] Wooldridge, J. M., 2009. On estimating firm-level production functions using proxy variables to control for unobservables. Economics Letters 104, 112-114.

[24] WTO (2010), Globalization and trade flows: what you see is not what you get! Staff Working Paper ERSD-2010-12. 


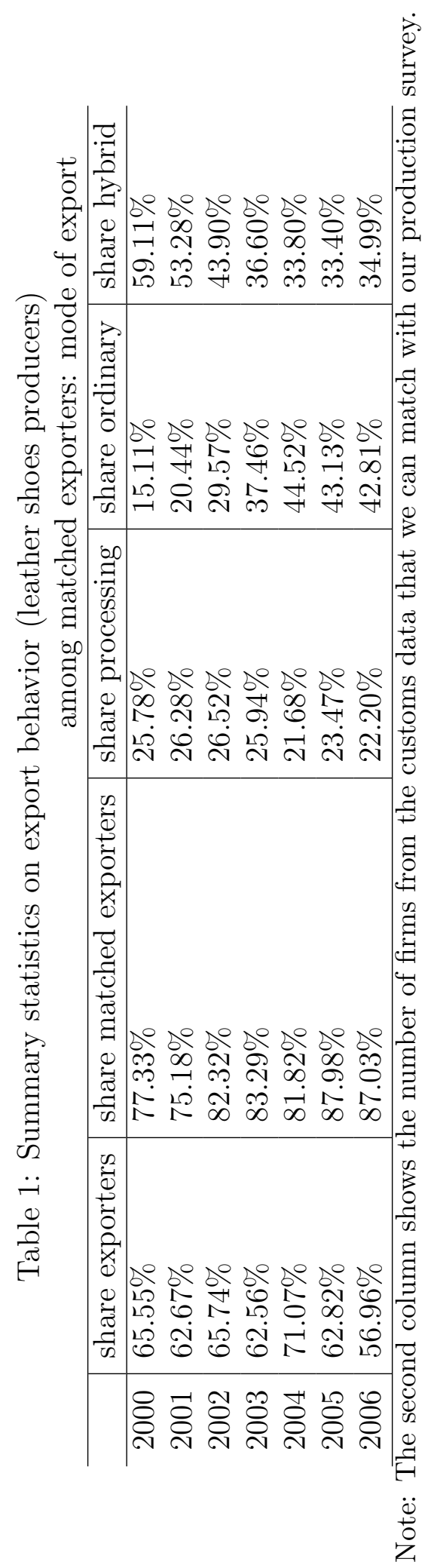




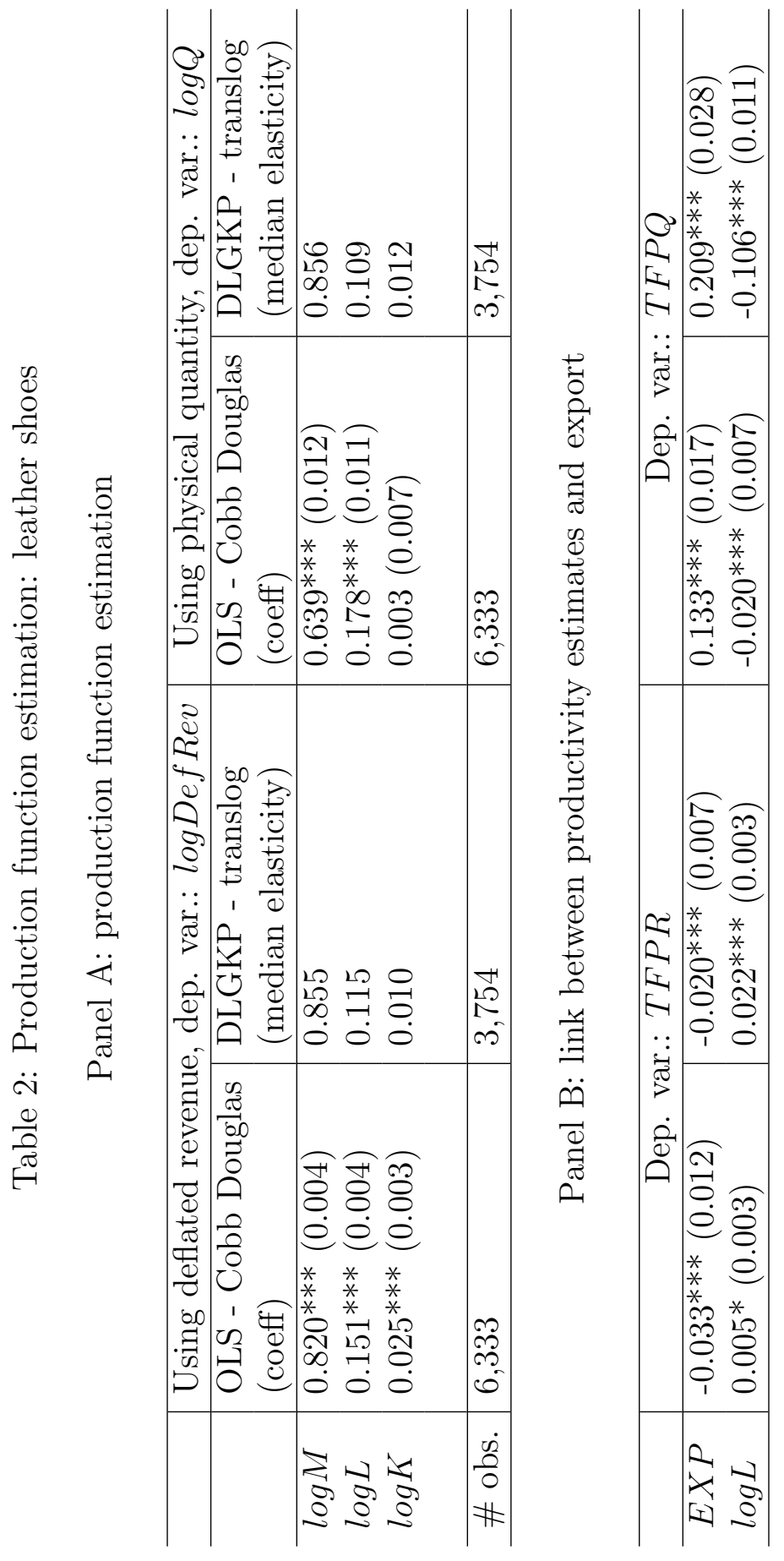




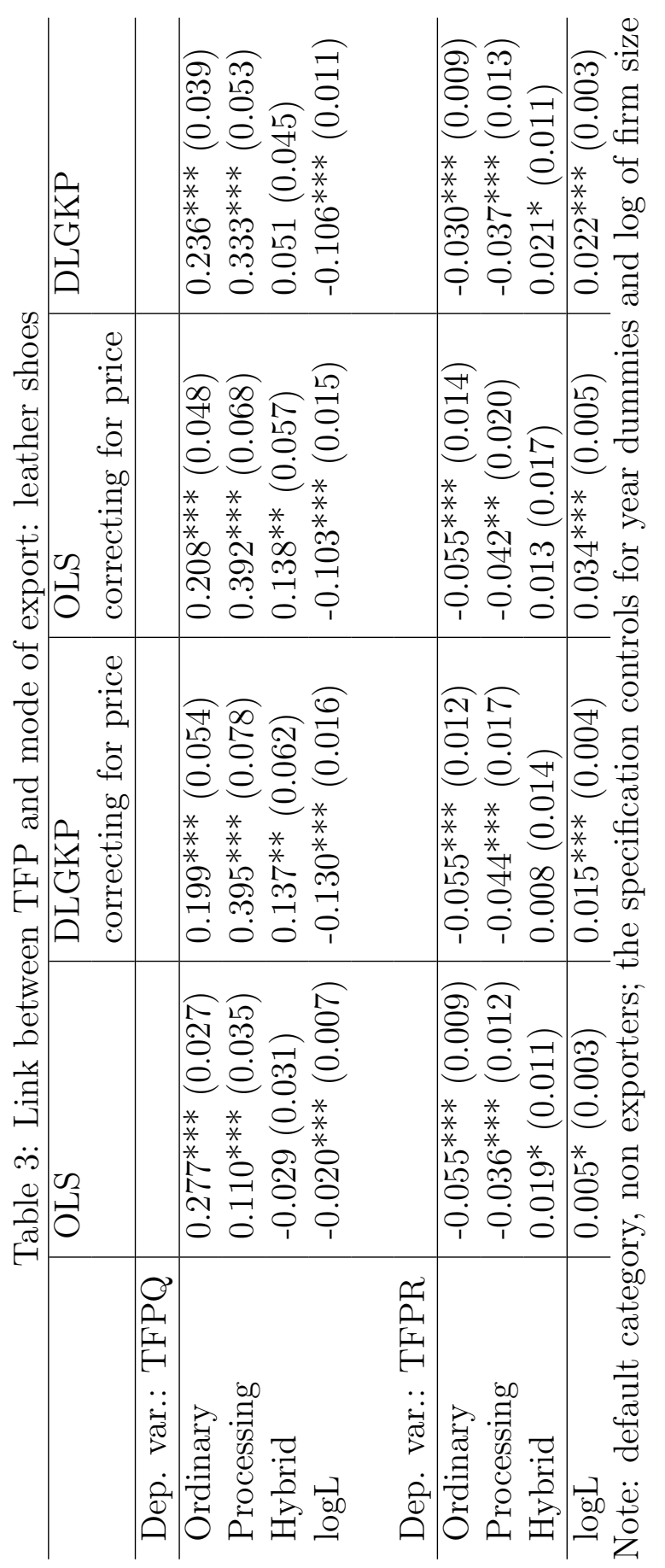


Table 4: Export price, mode of transaction and production price (matched exporters only)

\begin{tabular}{l|l|l|l} 
Dep. var.: logpexp & $(1)$ & $(2)$ & $(3)$ \\
\hline processing & $-0.094^{* * *}$ & - & $-0.026^{*}$ \\
& $(0.018)$ & & $(0.015)$ \\
logp & - & $0.416^{* * *}$ & $0.414^{* * *}$ \\
& & $(0.008)$ & $(0.008)$ \\
cons & $1.376^{* * *}$ & $-1.181^{* * *}$ & $-1.153^{* * *}$ \\
& $(0.033)$ & $(0.057)$ & $(0.059)$ \\
\hline HS6 dummies & \multicolumn{3}{|c}{ YES } \\
Year dummies & \multicolumn{3}{|c}{ YES } \\
\hline $\mathrm{r} 2$ & 0.243 & 0.460 & 0.461 \\
$\mathrm{~N}$ & \multicolumn{3}{|c}{5,992} \\
\hline
\end{tabular}

Table 5: Distribution of ownership type by mode of export (matched exporters only)

\begin{tabular}{l|l|l} 
& \# firms (\%) & share processing \\
\hline dom priv & 412 & $1.46 \%$ \\
& $(18.25 \%)$ & \\
\multirow{2}{*}{ other } & 299 & $6.69 \%$ \\
& $(13.24 \%)$ & \\
jv & 780 & $20.26 \%$ \\
OECD & $(34.54 \%)$ & \\
& 274 & $36.86 \%$ \\
HKMTW & $(12.13 \%)$ & \\
& 493 & $46.86 \%$ \\
& $(21.83 \%)$ & \\
\hline
\end{tabular}


Table 6: Link between TFP and export behavior (with controls for ownership and location)

\begin{tabular}{l|l|l|l} 
Dep. var. : & TFPQ & $\operatorname{logp}$ & TFPR \\
\hline \multirow{2}{*}{ exp } & $0.087^{* * *}$ & $-0.085^{* * *}$ & 0.001 \\
& $(0.023)$ & $(0.023)$ & $(0.008)$ \\
jv & $-0.069^{*}$ & $0.084^{* *}$ & 0.015 \\
& $(0.031)$ & $(0.031)$ & $(0.010)$ \\
other & -0.040 & 0.050 & 0.010 \\
& $(0.027)$ & $(0.027)$ & $(0.009)$ \\
OECD & $-0.100^{*}$ & $0.104^{*}$ & 0.006 \\
& $(0.044)$ & $(0.044)$ & $(0.015)$ \\
HKMTW & $0.109^{* *}$ & $-0.116^{* *}$ & -0.009 \\
& $(0.038)$ & $(0.039)$ & $(0.013)$ \\
logL & $-0.106^{* * *}$ & $0.123^{* * *}$ & $0.018^{* * *}$ \\
& $(0.010)$ & $(0.011)$ & $(0.004)$ \\
cons & $10.673^{* * *}$ & $-4.063^{* * *}$ & $13.521^{* * *}$ \\
& $(0.061)$ & $(0.061)$ & $(0.021)$ \\
\hline location dummies & \multicolumn{3}{|c}{ YES } \\
year dummies & \multicolumn{3}{|l}{ YES } \\
\hline r2 & 0.542 & 0.556 & 0.200 \\
$\mathrm{~N}$ & 3,731 & 3,731 & 3,731 \\
\hline
\end{tabular}


Table 7: Link between TFP and mode of transaction (with controls for ownership and location)

\begin{tabular}{l|l|l|l} 
Dep. var. : & TFPQ & logp & TFPR \\
\hline \multirow{2}{*}{ Processing } & $0.148^{* * *}$ & $-0.099^{*}$ & $0.050^{* * *}$ \\
& $(0.057)$ & $(0.058)$ & $(0.018)$ \\
Ordinary & -0.014 & 0.001 & -0.012 \\
& $(0.033)$ & $(0.033)$ & $(0.010)$ \\
Hybrid & 0.043 & -0.006 & $0.038^{* * *}$ \\
& $(0.043)$ & $(0.044)$ & $(0.014)$ \\
jv & -0.003 & -0.006 & -0.011 \\
& $(0.037)$ & $(0.038)$ & $(0.012)$ \\
other & -0.037 & 0.033 & -0.004 \\
& $(0.033)$ & $(0.033)$ & $(0.010)$ \\
OECD & 0.037 & -0.037 & 0.000 \\
HKMTW & $(0.053)$ & $(0.053)$ & $(0.017)$ \\
& $0.205^{* * *}$ & $-0.233^{* * *}$ & $-0.030^{* *}$ \\
logL & $(0.048)$ & $(0.048)$ & $(0.015)$ \\
& $-0.104^{* * *}$ & $0.120^{* * *}$ & $0.018^{* * *}$ \\
cons & $(0.013)$ & $(0.013)$ & $(0.004)$ \\
& $10.623^{* * *}$ & $-4.000^{* * *}$ & $13.534^{* * *}$ \\
\hline location dummies & $(0.072)$ & $(0.073)$ & $(0.023)$ \\
year dummies & \multicolumn{3}{|c}{ YES } \\
\hline r2 & 0.587 & YES \\
N & 2,548 & 2,5478 & 0.226 \\
\hline
\end{tabular}


Table 8: Link between TFP and mode of transaction (with controls for ownership and location)

\begin{tabular}{l|l|l|l} 
Dep. var. : & TFPQ & $\log$ & TFPR \\
\hline \multirow{2}{*}{ Processing with imp. inputs } & -0.050 & $0.098^{*}$ & $0.053^{* * *}$ \\
& $(0.053)$ & $(0.054)$ & $(0.018)$ \\
Pure assembly & $0.652^{* * *}$ & $-0.628^{* * *}$ & 0.016 \\
Ordinary & $(0.073)$ & $(0.074)$ & $(0.024)$ \\
hybrid & -0.028 & 0.016 & -0.011 \\
& $(0.032)$ & $(0.032)$ & $(0.011)$ \\
jv & 0.011 & 0.047 & $0.058^{* * *}$ \\
other & $(0.051)$ & $(0.051)$ & $(0.017)$ \\
& 0.001 & -0.009 & -0.010 \\
OECD & $(0.037)$ & $(0.037)$ & $(0.012)$ \\
HKMTW & -0.040 & 0.035 & -0.005 \\
& $(0.033)$ & $(0.033)$ & $(0.011)$ \\
l & 0.056 & -0.058 & -0.002 \\
& $(0.052)$ & $(0.052)$ & $(0.017)$ \\
cons & $0.220^{* * *}$ & $-0.248^{* * *}$ & $-0.031^{* *}$ \\
r2 & $(0.047)$ & $(0.047)$ & $(0.016)$ \\
N & $-0.092^{* * *}$ & $0.107^{* * *}$ & $0.016^{* * *}$ \\
\hline
\end{tabular}




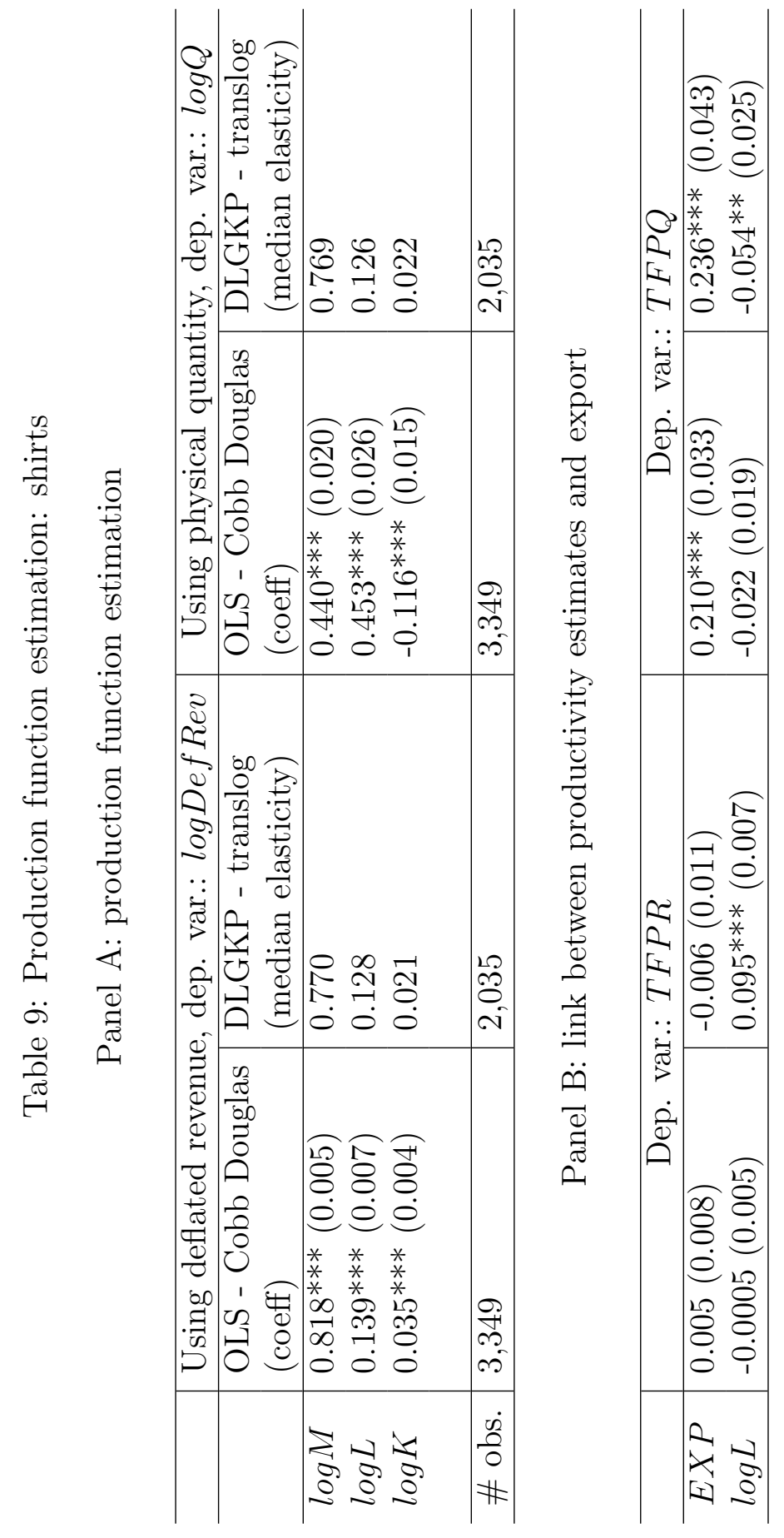




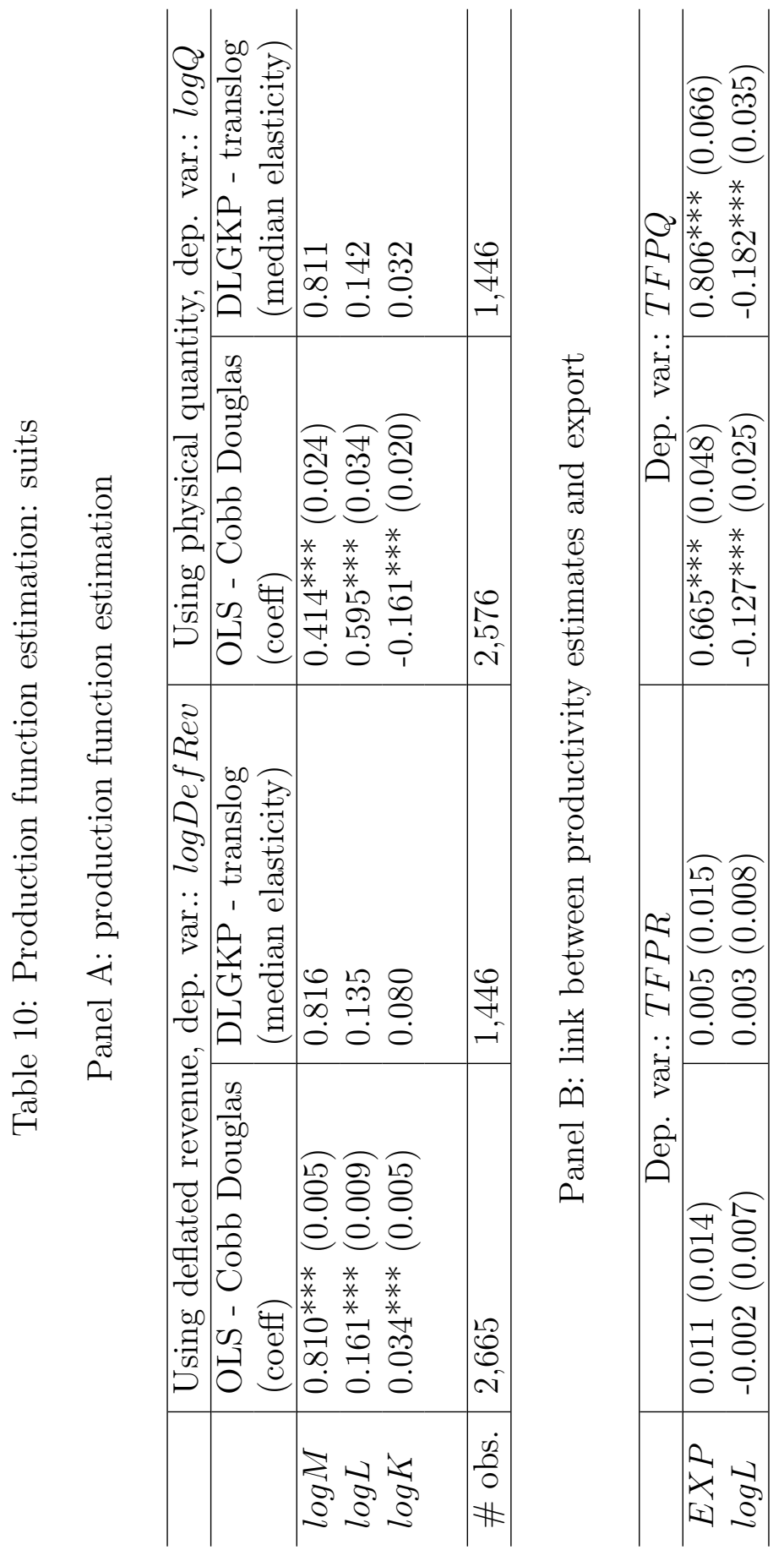

